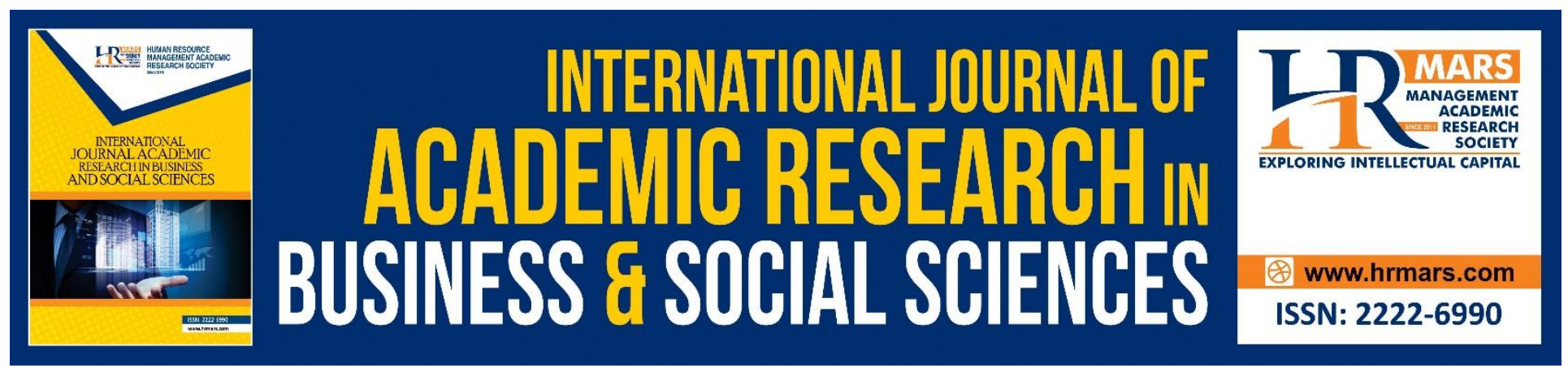

\title{
Mentoring Supports for Engaging University Students in Entrepreneurship Activities
}

Fathiah Nabila Mohamad Daud, Adriana Mohd. Rizal, Suzilawati Kamarudin, Nazimah Hussin and Rafidah Othman

To Link this Article: http://dx.doi.org/10.6007/IJARBSS/v9-i1/5420

DOI: $\quad 10.6007 /$ IJARBSS/v9-i1/5420

Received: 29 Dec 2018, Revised: 17 Jan 2019, Accepted: 30 Jan 2019

Published Online: 03 Feb 2019

In-Text Citation: (Daud, Rizal, Kamarudin, Hussin, \& Othman, 2019)

To Cite this Article: Daud, F. N. M., Rizal, A. M., Kamarudin, S., Hussin, N., \& Othman, R. (2019). Mentoring Supports for Engaging University Students in Entrepreneurship Activities. International Journal of Academic Research in Business and Social Sciences, 9(443-454).

Copyright: (c) 2019 The Author(s)

Published by Human Resource Management Academic Research Society (www.hrmars.com)

This article is published under the Creative Commons Attribution (CC BY 4.0) license. Anyone may reproduce, distribute, translate and create derivative works of this article (for both commercial and non-commercial purposes), subject to full attribution to the original publication and authors. The full terms of this license may be seen at: http://creativecommons.org/licences/by/4.0/legalcode

Vol. 9, No. 1, 2019, Pg. 443 - 454

http://hrmars.com/index.php/pages/detail/IJARBSS

JOURNAL HOMEPAGE

Full Terms \& Conditions of access and use can be found at http://hrmars.com/index.php/pages/detail/publication-ethics 


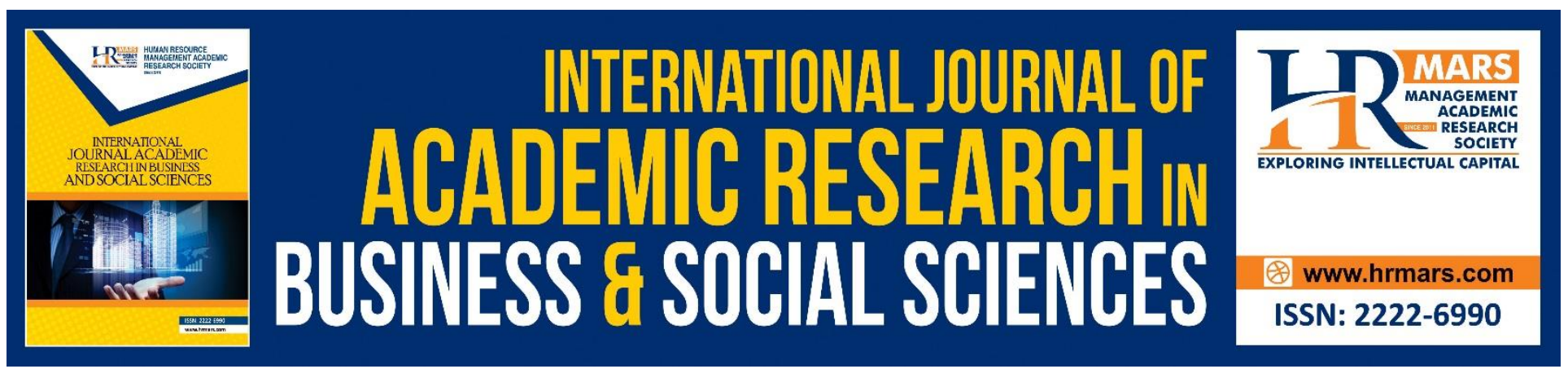

\title{
Mentoring Supports for Engaging University Students in Entrepreneurship Activities
}

\author{
Fathiah Nabila Mohamad Daud ${ }^{1}$, Adriana Mohd. Rizal ${ }^{*}$, Suzilawati \\ Kamarudin ${ }^{3}$, and Nazimah Hussin ${ }^{4}$ and Rafidah Othman ${ }^{5}$ \\ 1,2,3,4,5 Azman Hashim International Business School, Level 10, Menara Razak, Universiti Teknologi \\ Malaysia, Jalan Sultan Yahya Petra, 54100 Kuala Lumpur.
}

\begin{abstract}
Mentors play important roles with their mentees' career development, psychosocial as well as role modelling. They assist novice entrepreneurs to identify opportunity in business. Yet, there are a small number of researches focusing on mentoring impacts especially among university students. This is vital to increase students' interests to be involved in entrepreneurship activities and becoming entrepreneurs. Besides, it has been the national agenda of many countries to embed entrepreneurship at the universities level due to graduate employability issue. This agenda not only focusing on job creation only but also equipping students with entrepreneurial mindset and skills. The objective of this study is to review the literature on types of mentoring supports for engaging university students in entrepreneurship activities.
\end{abstract}

Keywords: Mentoring, Mentoring Supports, Entrepreneurship Program, Entrepreneurship Activities.

\section{Introduction}

Entrepreneurship has become the heroes in improving economies and to solve unemployment issues in many countries of the world (Nutu et al. 2016). Therefore, a number of universities and policymakers all over the world are encouraging entrepreneurship activities to stimulate economic growth and job creation (Eesley and Wang 2014). Recent studies found that it is important to focus on university-based entrepreneurship as it has impact on economy (Harhoff 1999; Shane 2004; Roberts and Eesley 2011; Eesley and Miller 2012). Numerous governments, universities and industry have participated and started the programmes which embedded mentoring as a prime component in boosting entrepreneurship (Eesley and Wang 2014). According to Edelman et al. (2016), education starts from the primary and secondary schools and even in the university. Chia (1996) points out that universities and business schools play an important role in cultivating the entrepreneurial imagination and mentoring as one of the methods that can be adopted in tying academic learning to real world by providing the links between pedagogical theories to actual business methods (Robinson and Haynes 1991). Based on past studies, entrepreneurship education is important by helping the 
students to engage in entrepreneurship activities while studying and indirectly contributing to enhancement of students' knowledge. Literature also suggests that mentoring induces students' likelihood to get involved in entrepreneurship activities. In Malaysian context, entrepreneurship has always been the priority of MOHE to stimulate innovation and entrepreneurship among educated individuals as MOHE is concerned with employability among the graduates. Research showed that most of the students after graduation failed to secure jobs. About 35 percent remains unemployed and majority of them are degree holders (Leo 2018). The unemployment has been one of the issues as the effects of the instability of the demand and the economic crisis. According to Chigunta (2001) and Schoof (2006), this problem has urged the societies to initiate self-job especially among the young generations. That is why the entrepreneurship has become one of the agendas and initiatives by the government. Through government agencies such as MOHE, the entrepreneurship subject has become one of the core subjects at the university. Starting from 1 January 2017, students from the public and private higher learning institutions will be exempted from any fees when they register their new ventures at the Companies Commissions of Malaysia (Companies Commissions of Malaysia 2016). This initiative highlights the government's intention to get students engage in entrepreneurship activities while studying. Many universities around the world have met the challenge to become a more 'entrepreneurial university' by setting up university-centred innovation systems in their economy, locality and regionality (Etzkowitz et al. 2000; Rasmussen et al. 2006). These new trends make the number of entrepreneurships programmes in universities to increase rapidly including Malaysian universities. However, the students need to be guided. Literature highlights that lack of management skills for novice entrepreneurs is one of the main reasons for a business' failure. This is due to their inexperience in dealing with problems and managing limited resources. As a result, they outsourced so many tasks such as marketing, product and services development, and human resource management (Gartner et al.1999). According to Nutu et al. (2016), many of the entrepreneurial skills need to be learned outside the classroom. Thus, it is important for the entrepreneurs to learn from someone through mentoring or programmes and entrepreneurs' clubs. Nonetheless, in the entrepreneurship literature, mentoring has been given a little attention (St-Jean and Audet 2009; Gordon 2007; Ozgen and Baron 2007; St-Jean and Audet 2012; St-Jean et al. 2017). They also suggest that mentors can assist novice entrepreneurs to identify opportunity in business. Yet, there are a small number of the research focusing on mentoring impacts on start-up process. In addition, St-Jean et al. (2017) asserts that research on formal mentoring should be implemented by the university to increase students' interests in becoming entrepreneurs. The objective of this study is to review the types of mentoring supports literature among university students.

\section{Literature Review}

\section{Mentoring Entrepreneurship}

Kram (1983) defines mentor as someone who is more senior than the mentee. These mentors usually already have vast experiences and succeeded in their fields. They coach junior mentees in various aspect including career development, psychosocial as well as role modelling. Gay (1994) defines mentoring as a relationship between the youth that give support, assistance, assistance or even guidance during the crisis phase of the other younger youth. In entrepreneurial mentoring, a mentor 
does not involve in the business and mentoring entrepreneurs provide personalized, flexible support according to each situation (Cull 2006; St-Jean and Audet 2012; Sullivan 2000; Waters and Birrell 2007). A role model function has been confirmed as the mentoring function in the context of entrepreneurship (St-Jean 2011). According to Cull (2006), mentors' experiences avoid mentees from making costly errors in businesses. Mentors provide psychological and career-related functions. In psychological function, mentors give reflection, reassurance, motivation and confidant. In entrepreneurial career-related function, mentors assist mentees in integration, information support, confrontation and guide (St-Jean 2011). According to Cope and Watts (2000), mentoring is a learning intervention that has relation to the entrepreneurs who have experience and reactions towards critical incidents or situation that will be important in the learning process. Mentors can enhance the learning process by converting their own knowledge into the compatible form to their mentees (Morrison and Bergin-Seers 2002). Furthermore, mentoring is most relevant towards entrepreneurs' personal development (Hudson-Davies et al. 2002) because not only mentors become positive role models but also, they inspire their mentees to emulate them (Lockwood et al. 2002). The literature review on entrepreneurship mentoring shows that mentoring gives support to those in learning or been called as protégé. It also shows a positive relationship that mentoring provide benefits to students in the context of university. In short, mentoring is a form of support for entrepreneurs (StJean and Audet 2009).

\section{Mentoring Support That Influence Students to Be Involved in Entrepreneurship Activities}

Past research shows that finance, motivation and social networking are the types of mentoring support needed by students to be involved in entrepreneurship activities. Gibson (2005) states that mentoring is different from other types of support as the mentor plays an important role in giving an absolute support and not just part of it. Likewise, many programs which involved mentoring have been developed in big organizations generally comprises of financial and networking supports. In this research context, finance, motivation and networking are identified as the types of students' mentoring support which influenced students get involved in entrepreneurship activities.

\section{Finance}

The role of mentoring supports for young people are not only coming from the family, society and company or business but also the universities. It has become the responsibility of the universities as many nations and regions already have the policies to encourage university's based new ventures (Grimaldi et al. 2011). This initiative leads to an increase in the number of spin-offs companies (Clarysse et al. 2005). Massachusetts Institute of Technology (MIT) becomes an actor in entrepreneurial ecosystems in which it has high number of prospering technology ventures (Mason and Brown 2014). There are several characteristics that are critical to MIT success such as venture capital and extensive participation of government in shaping science and technology, and an entrepreneurial culture (Lee et al. 2000; O'Shea et al. 2007). Reynolds and Miller (1992) identify that two of the four important keys during the firm establishment are intention or commitment and financing. Previous studies also highlight that young entrepreneurs may have difficulties in funding start-ups because of inexperience and lack of skills to acquire credit facility (European Commission 
INTERNATIONAL JOURNAL OF ACADEMIC RESEARCH IN BUSINESS AND SOCIAL SCIENCES

Vol. 9, No. 1, Jan, 2019, E-ISSN: 2222-6990 @ 2019 HRMARS

2005; Schoof and Semlali 2008). Thus, this research emphasizes on the importance of financial support in university to influence students to get involved in entrepreneurship activities.

\section{Social Networking}

Past research claims that entrepreneurs regularly use networks to obtain ideas and converge information to identify entrepreneurial opportunities (Birley 1985; Smeltzer et al. 1991; Singh et al. 1999; Hoang and Young 2000). Networks can be used to access capital (Light 1984; Zimmer and Aldrich 1987; Bates and Bates 1997) although most research give attention to accessibility to intangible resources. Bruderl and Preisendorfer (1998) claim that network relations equip entrepreneurs with emotional support in terms of risk-taking and this mindset helps to increase persistence to stay in business (Gimeno et al. 1997). Woodward (1988) states that social networks play important roles in establishing and sustaining businesses, and successful entrepreneurs allocate more time in developing network contacts. Networks can be used for different purposes. One of the most significant purposes is providing access to entrepreneurial competencies in the new venture creation context (Hallen and Eisenhardt 2012). During this early stage of business formation, the development of competencies is necessary to make the changes from academic research to the exploitation and exploration of opportunities (Vohora et al. 2004). Social networks provide entrepreneurs with access to distribution channels, knowledge and support to help entrepreneurs develop their firms. Fernández-Péreza et al. (2015) state that in promoting academics interest towards new business ventures, business and personal networks have relatively positive impacts. Subsequently, the researchers have different opinion to what extent and how depth social networks have effects on opportunity recognition of an individual (Kingsley and Malecki 2004; Parker 2008). Certainly, exposure of social networks towards more opportunities can directly help new business (Audretcsch et al. 2008; Davidsson and Honig 2003). Thus, developing a social network through conferences, clubs or associations seminars and workshops related to entrepreneurship, students gain advantage in term of readiness towards starting up their firms in future.

\section{Motivation}

To face risks, entrepreneurs need to be mentally tough. In terms of psychosocial support, entrepreneurs receive support of others to share, trust, accept and feel as part of a group, and make friends (Leck et al. 2009; Witry et al. 2013). The mentor's presence can be considered as an expert which allows the start-up entrepreneurs to enhance or construct mental models (St-Jean and Audet 2012). McGregor and Tweed's (2002) study on businesswomen mentoring activities states that the mentors also provide motivation. In other studies, entrepreneurs receive psychosocial support in form of counselling and friendship (Kram 1988; Pellegrini and Scandura 2005). In retrospect, students who are not involved in entrepreneurship training or mentoring are lacking motivation. In fact, students with higher motivation are likely to be involved in entrepreneurship activities (Choo and Wong 2006; McClelland 1961; Pihie and Sanni 2009). To motivate students towards entrepreneurial readiness, students must have a motivation (Choo and Wong 2006). Motivation has a significant impact towards readiness on new venture creation. There are several components in entrepreneurial motivation that are identified in past studies including achievement motivation as one of the crucial factors that motivates individuals to entrepreneurship (Coduras et al. 2016; Ismail et al. 2012; Ruiz et 
INTERNATIONAL JOURNAL OF ACADEMIC RESEARCH IN BUSINESS AND SOCIAL SCIENCES

Vol. 9, No. 1, Jan, 2019, E-ISSN: 2222-6990 (C) 2019 HRMARS

al. 2016). McClelland (1961) states that achievement motive inspires entrepreneurship activity compared to profit motive.

\section{Entrepreneurship Activities}

Entrepreneurial activities can be translated as basic human activities whereas achievement is a creative process (Johannisson 2011; Lumpkin 2011; Steyeart 2007). Various models on entrepreneurship education programmes can be found in the national education system such as in primary and secondary schools, vocational institutions, tertiary and university levels. The models are developed informally inside the economy by targeting the unemployed person, potential young entrepreneurs (Haftendorn and Salzano 2004). Entrepreneurial education must be mixed with national curriculum in primary, secondary, vocational and higher education to increase and create awareness in education institutions. The start-up programmes allows government to cultivate positives perspectives on entrepreneurship activities for youths (Haftendorn and Salzano 2004). Mentors' support towards mentees helps to eliminate fears or concerns related to entrepreneurship activities (Kyrgidou et al. 2013) as mentees develop confident and security in eliminating the doubts (Kram 1988). Torrance (2013) highlights that the key ingredient needed by the university is to conduct entrepreneurship events by involving all university members. This is because entrepreneurship activities become more important especially for education (Cahn 2008). Recent study finds that entrepreneurship training has positive significant towards identification of opportunity and entrepreneurial readiness when involves in entrepreneurship activities (Olugbola 2017). In the context of this research, mentoring supports may influence students to get involved in entrepreneurship activities.

\section{Conceptual Framework}

This study's conceptual framework is developed based on the types of mentoring supports for engaging university students in entrepreneurship activities as discussed earlier in section 2.3 to 2.5. The mentoring supports are financial support, networking and motivation. The conceptual framework for the study is in Figure 1.

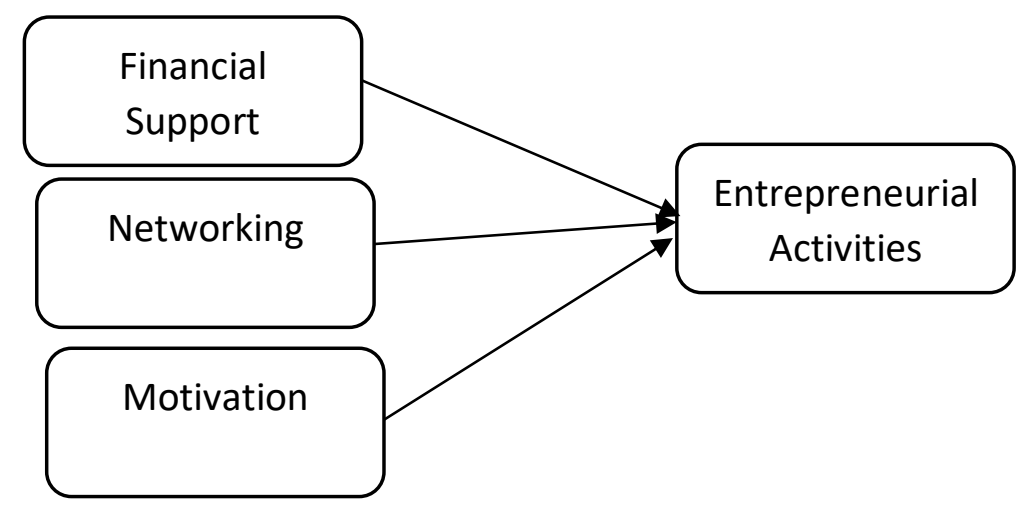

Figure 1: Mentoring Support for Engaging University Students in Entrepreneurial Activities 
INTERNATIONAL JOURNAL OF ACADEMIC RESEARCH IN BUSINESS AND SOCIAL SCIENCES

Vol. 9, No. 1, Jan, 2019, E-ISSN: 2222-6990 (C) 2019 HRMARS

\section{Conclusion and Future Research}

Three types of mentoring supports are identified that encourage students to engage in entrepreneurship activities. The three mentoring supports that are found in this paper are financial support, networking and motivation. For future research, other aspects of mentoring support should be highlighted as well as mentoring contexts such as in agencies. The future research can also focus on primary or secondary schools. Von Graevenitz et. al (2010) also states that the entrepreneurship education might convince people who are not keen in entrepreneurship to become entrepreneurs. Future research may focus on how mentoring can give confident to people who are not interested in entrepreneurship.

\section{Acknowledgement}

The study was supported by Universiti Teknologi Malaysia and Malaysian Ministry of Higher Education under Research University Grant Tier 1 (RUG of UTM), No.: Q.K130000.2563.16H52, entitled - Exploring Municipal Solid Waste Incineration Plant Operations in Malaysia.

\section{Corresponding Author}

Adriana Mohd Rizal

Azman Hashim International Business School, Level 10, Menara Razak, Universiti Teknologi

Malaysia, Jalan Sultan Yahya Petra, 54100 Kuala Lumpur.

E-mail: adriana.kl@utm.my

\section{References}

Audretcsch, D. B., Bonte, W., \& Keilbach, M. (2008). Entrepreneurship capital and its impact on knowledge diffusion and economic performance. Journal of Business Venturing, 23(6), 687698.

Bates, T., \& Bates, T. M. (1997). Race, self-employment, and upward mobility: An illusive American dream. Woodrow Wilson Center Press.

Birley, S. (1985). The role of networks in the entrepreneurial process. Journal of business venturing, 1(1), 107-117.

Brüderl, J., \& Preisendörfer, P. (1998). Network support and the success of newly founded business. Small business economics, 10(3), 213-225.

Cahn, M. (2008). Indigenous entrepreneurship, culture and micro-enterprise in the Pacific Islands: case studies from Samoa. Entrepreneurship and regional development, 20(1), 1-18.

Chia, R. (1996). Teaching paradigm shifting in management education: University business schools and the entrepreneurial imagination. Journal of management Studies, 33(4), 409-428.

Chigunta, F. (2001). An analysis of institutional intervention for promotign youth enterprise development in Sub-Saharan Africa with reference to South Africa. In Proc in Conference on Development and Transformation at the Cross Roads in South Africa: Challenges of the 21st Century Empowering South Africa Youth for the 21st Century.

Clarysse, B., Wright, M., Lockett, A., Van de Velde, E., \& Vohora, A. (2005). Spinning out new ventures: a typology of incubation strategies from European research institutions. Journal of Business venturing, 20(2), 183-216. 
INTERNATIONAL JOURNAL OF ACADEMIC RESEARCH IN BUSINESS AND SOCIAL SCIENCES

Vol. 9, No. 1, Jan, 2019, E-ISSN: 2222-6990 @ 2019 HRMARS

Choo, S., \& Wong, M. (2006). Entrepreneurial intention: Triggers and barriers to new venture creations in Singapore. Singapore Management Review, 28(2).

Coduras, A., Saiz-Alvarez, J. M., \& Ruiz, J. (2016). Measuring readiness for entrepreneurship: An information tool proposal. Journal of Innovation \& Knowledge, 1, 99-108.

Companies Commissions of Malaysia. (2016). Pendaftaran Perniagaan Secara Percuma Melalui Skim 1Pelajar 1Pendaftaran Perniagaan. Retrieved from http://www.ssm.com.my/bm/Pages/Services/Registration-of-Business-(ROB)/1Student1Business-Registration-Scheme.aspx

Cope, J., \& Watts, G. (2000). Learning by doing-an exploration of experience, critical incidents and reflection in entrepreneurial learning. International Journal of Entrepreneurial Behavior \& Research, 6(3), 104-124.

Cull, J. (2006). Mentoring young entrepreneurs: what leads to success?. International journal of evidence based coaching and mentoring, 4(2), 8-18.

Davidsson, P. \& Honig, B. (2003). The role of social and human capital among nascent entrepreneurs. Journal of Business Venturing, 18(3), 301-333.

Department of Statistics Malaysia. (2018, September). Key Statistics of Labour Force in Malaysia, September $2018 . \quad$ Retrieved from https://www.dosm.gov.my/v1/index.php?r=column/cthemeByCat\&cat=124\&bul_id=TmgwQ0 R2a2VteHM3SEg0aUJqU25UZz09\&menu_id=U3VPMIdoYUxzVzFaYmNkWXZteGduZz09

Eesley, C. E., \& Wang, Y. (2014). The Effects of Mentoring in Entrepreneurial Career Choice. Boston U. School of Management Research Paper, 2387329.

Eesley, C. E., \& Roberts, E. B. (2012). Are you experienced or are you talented?: When does innate talent versus experience explain entrepreneurial performance?. Strategic Entrepreneurship Journal, 6(3), 207-219.

Edelman, L. F., Manolova, T., Shirokova, G., \& Tsukanova, T. (2016). The impact of family support on young entrepreneurs' start-up activities. Journal of Business Venturing, 31(4), 428-448. Retrieved from http://doi.org/10.1016/j.jbusvent.2016.04.003

Eisenhardt, K. M. (1989). Building theories from case study research. Academy of management review, 14(4), 532-550.

Etzkowitz, H., Webster, A., Gebhardt, C., \& Terra, B. R. C. (2000). The future of the university and the university of the future: evolution of ivory tower to entrepreneurial paradigm. Research policy, 29(2), 313-330.

European Commission. (2005, March 25). The new SME definition: User guide and model declaration. Retrieved from https://ec.europa.eu/digital-single-market/en/news/new-sme-definition-userguide-and-model-declaration.

Fernández-Pérez, V., Alonso-Galicia, P. E., Rodríquez-Ariza, L., \& del Mar Fuentes-Fuentes, M. (2015). Professional and personal social networks: A bridge to entrepreneurship for academics?. European Management Journal, 33(1), 37-47.

Gartner, W., Starr, J., \& Bhat, S. (1999). Predicting new venture survival: an analysis of "anatomy of a start-up." cases from Inc. Magazine. Journal of Business Venturing, 14(2), 215-232.

Gay, B. (1994). What is mentoring?. Education+ Training, 36(5), 4-7. 
INTERNATIONAL JOURNAL OF ACADEMIC RESEARCH IN BUSINESS AND SOCIAL SCIENCES

Vol. 9, No. 1, Jan, 2019, E-ISSN: 2222-6990 (C) 2019 HRMARS

Gibson, S. K. (2005). Whose best interests are served? The distinction between mentoring and support. Advances in Developing Human Resources, 7(4), 470-488. doi:10.1177/1523422305279678.

Gimeno, J., Folta, T. B., Cooper, A. C., \& Woo, C. Y. (1997). Survival of the fittest? Entrepreneurial human capital and the persistence of underperforming firms. Administrative science quarterly, 750-783.

Gordon, S. R. (2007). Interpersonal trust, vigilance and social networks roles in the process of entrepreneurial opportunity recognition. International Journal of Entrepreneurship and Small Business, 4(5), 564-585. doi:10.1504/IJESB.2007.014390.

Grimaldi, R., Kenney, M., Siegel, D. S., \& Wright, M. (2011). 30 years after Bayh-Dole: Reassessing academic entrepreneurship. Research Policy, 40(8), 1045-1057.

Haftendorn, K., \& Salzano, C. (2004). Facilitating youth entrepreneurship (No. 993669173402676). International Labour Organization.

Hallen, B. L., \& Eisenhardt, K. M. (2012). Catalyzing strategies and efficient tie formation: How entrepreneurial firms obtain investment ties. Academy of Management Journal, 55(1), 35-70.

Harhoff, D. (1999). Firm formation and regional spillovers-evidence from Germany. Economics of Innovation and New Technology, 8(1-2), 27-55.

Hoang, H., \& Young, N. (2000). Social embeddedness and entrepreneurial opportunity recognition:(more) evidence of embeddedness. Frontiers of Entrepreneurship Research, Babson College, Wellesley, MA.

Hudson-Davies, R., Parker, C., \& Byrom, J. (2002). Towards a healthy high street: developing mentoring schemes for smaller retailers. Industrial and commercial training, 34(7), 248-255.

Johannisson, B. (2011). Towards a practice theory of entrepreneuring. Small business economics, 36(2), 135-150.

Ismail, K., Ahmad, R., Gadar, K., \& Yunus, N. (2012). Stimulating factors on women entrepreneurial intention. Business Management Dynamics, 2(6), 20-28.

Kingsley, G., \& Malecki, E. J. (2004). Networking for competitiveness. Small Business Economics, 23(1), 71-84.

Kram, K. E. (1983). Phases of the mentor relationship. Academy of Management journal, 26(4), 608625.

Kram, K. E. (1988). Mentoring at work: Developmental relationships in organizational life. University Press of America.

Kyrgidou, L. P., \& Petridou, E. (2013). Developing women entrepreneurs' knowledge, skills and attitudes through e-mentoring support.Journal of Small Business and Enterprise Development, 20(3), 548-566.

Leck, J., Orser, B., \& Riding, A. (2009). An examination of gender influences in career mentoring. Canadian Journal of Administrative Sciences/Revue Canadienne des Sciences de I'Administration, 26(3), 211-229.

Lee, C. M. (2000). The Silicon Valley edge: A habitat for innovation and entrepreneurship. Stanford University Press. 
INTERNATIONAL JOURNAL OF ACADEMIC RESEARCH IN BUSINESS AND SOCIAL SCIENCES

Vol. 9, No. 1, Jan, 2019, E-ISSN: 2222-6990 @ 2019 HRMARS

Leo, M. (2018, June 2018). What You Didn't Know About Fresh Graduate Unemployment in Malaysia [Infographic]. Retrieved from https://eduadvisor.my/articles/what-didnt-know-freshgraduate-unemployment-malaysia-infographic/

Light, I. (1984). Immigrant and ethnic enterprise in North America. Ethnic and racial studies, 7(2), 195216.

Lockwood, P., Jordan, C. H., \& Kunda, Z. (2002). Motivation by positive or negative role models: regulatory focus determines who will best inspire us. Journal of personality and social psychology, 83(4), 854.

Lumpkin, G. T. (2011). From legitimacy to impact: Moving the field forward by asking how entrepreneurship informs life. Strategic Entrepreneurship Journal, 5(1), 3-9.

Mason, C., \& Brown, R. (2014). Entrepreneurial ecosystems and growth oriented entrepreneurship. Final Report to OECD, Paris, 30(1), 77-102.

McClelland, D. C. (1961). The achieving society. Princeton, NJ: Van Nostrand

McGregor, J., \& Tweed, D. (2002). Profiling a new generation of female small business owners in New Zealand: Networking, mentoring and growth. Gender, Work \& Organization, 9(4), 420-438.

Morrison, A. \& Bergin-Seers, S. (2002). Pro-growth small businesses: learning 'architecture'. Journal of Management Development, 21(5/6), 388-405.

Nutu, I. V., Munteanu, A. R., \& Pîrlog, R. N. (2016). Impact Factors for The Development of Young Entrepreneurs In Romania. SEA: Practical Application of Science, 4(3).

Olugbola, S. A. (2017). Exploring entrepreneurial readiness of youth and startup success components: Entrepreneurship training as a moderator. Journal of Innovation \& Knowledge, 2(3), 155-171. http://doi.org/10.1016/j.jik.2016.12.004

O'Shea, R. P., Allen, T. J., Morse, K. P., O'Gorman, C., \& Roche, F. (2007). Delineating the anatomy of an entrepreneurial university: the Massachusetts Institute of Technology experience. $R \& d$ Management, 37(1), 1-16.

Ozgen, E., \& Baron, R. A. (2007). Social sources of information in opportunity recognition: effects of mentors, industry networks, and professional forums. Journal of Business Venturing, 22(2), 174-192. doi:10.1016/j.jbusvent.2005.12.001.

Parker, S. C. (2008). The economics of formal business networks. Journal of Business Venturing, 23(6), 627-640.

Pellegrini, E. K., \& Scandura, T. A. (2005). Construct equivalence across groups: An unexplored issue in mentoring research. Educational and Psychological Measurement, 65(2), 323-335.

Pihie, Z. A. L., \& Sanni, A. S. A. (2009). Exploring the entrepreneurial mindset of students: Implication for improvement of entrepreneurial learning at university. Journal of International Social Research, 2(8), 340-345.

Rasmussen, E., Moen, $\varnothing$., \& Gulbrandsen, M. (2006). Initiatives to promote commercialization of university knowledge. Technovation, 26(4), 518-533.

Robinson, P., \& Haynes, M. (1991). Entrepreneurship education in America's major universities. Entrepreneurship Theory and Practice, 15(3), 41-52.

Roberts, E. B., \& Eesley, C. E. (2011). Entrepreneurial impact: The role of MIT. Foundations and Trends ${ }^{\circledR}$ in Entrepreneurship, 7(1-2), 1-149. 
INTERNATIONAL JOURNAL OF ACADEMIC RESEARCH IN BUSINESS AND SOCIAL SCIENCES

Vol. 9, No. 1, Jan, 2019, E-ISSN: 2222-6990 @ 2019 HRMARS

Reynolds, P., \& Miller, B. (1992). New firm gestation: Conception, birth, and implications for research. Journal of business venturing, 7(5), 405-417.

Ruiz, J., Soriano, D. R., \& Coduras, A. (2016). Challenges in measuring readiness for entrepreneurship. Management Decision, 54(5).

Schoof, U. (2006). Stimulating Youth Entrepreneurship: Barriers and incentives to enterprise start-ups by young people (No. 993881573402676). International Labour Organization.

Schoof, U., \& Semlali, A. (2008). Youth Entrepreneurship Measures to overcome the barriers facing youth. Youth and Children, 1-6.

Shane, S. A. (2004). Academic entrepreneurship: University spinoffs and wealth creation. Edward Elgar Publishing.

Smeltzer, L. R., Van Hook, B. L., \& Hutt, R. W. (1991). Analysis of the use of advisors as information sources in venture startups. Journal of Small Business Management, 29(3), 10.

Singh, R. P., Hills, G. E., Lumpkin, G. T., \& Hybels, R. C. (1999, August). The entrepreneurial opportunity recognition process: Examining the role of self-perceived alertness and social networks. In Academy of Management Proceedings(Vol. 1999, No. 1, pp. G1-G6). Briarcliff Manor, NY 10510: Academy of Management.

Stake, R. E. (1995). The art of case study research. Sage.

Steyaert, C. (2007). 'Entrepreneuring'as a conceptual attractor? A review of process theories in 20 years of entrepreneurship studies. Entrepreneurship and regional development, 19(6), 453477.

St-Jean, E., \& Audet, J. (2009). Factors Leading to Satisfaction in a Mentoring Scheme for Novice Entrepreneurs. International Journal of Evidence Based Coaching \& Mentoring, $7(1)$.

St-Jean, E. (2011). MENTOR FUNCTIONS FOR NOVICE ENTREPRENEURS. Academy of Entrepreneurship Journal, 17(1).

St-Jean, E., \& Audet, J. (2012). The role of mentoring in the learning development of the novice entrepreneur. International Entrepreneurship and Management Journal, 8(1), 119-140.

St-Jean, É., Tremblay, M., Janssen, F., Baronet, J., Loué, C., \& Nafa, A. (2017). May business mentors act as opportunity brokers and enablers among university students?. International Entrepreneurship and Management Journal, 13(1), 97-111.

Sullivan, R. (2000). Entrepreneurial learning and mentoring. International Journal of Entrepreneurial Behavior \& Research, 6(3), 160-175.

Torrance, W. E. (2013). Entrepreneurial Campuses: Action, Impact, and Lessons Learned from the Kauffman Campuses Initiative. Ewing Marion Kauffman Foundation Research Paper.

Vohora, A., Wright, M., \& Lockett, A. (2004). Critical junctures in the development of university hightech spinout companies. Research policy, 33(1), 147-175.

Von Graevenitz, G., Harhoff, D., \& Weber, R. (2010). The effects of entrepreneurship education. Journal of Economic Behavior \& Organization, 76(1), 90-112.

Waters, L., \& Birrell, S. (2007). The role of mentoring and peer support in contributing to perceived progress towards small business success: a cross sectional study. International Journal of Organisational Behaviour, 12(1), 33-48. 
Witry, M. J., Patterson, B. J., \& Sorofman, B. A. (2013). A qualitative investigation of protégé expectations and proposition of an evaluation model for formal mentoring in pharmacy education. Research in Social and Administrative Pharmacy, 9(6), 654-665.

Yin, R.K., (1994), Case study research: Design \& methods (2nd ed), Sage: London.

Yin, R. K. (2003). Case study research: Design and methods (revised 2nd ed.). Newbury Park, CA: Sage.

Zimmer, C., \& Aldrich, H. (1987). Resource mobilization through ethnic networks: Kinship and friendship ties of shopkeepers in England. Sociological perspectives, 30(4), 422-445. 